\title{
CORRELATION OF EXCESS ENTHALPY AND HELIUM-4 PRODUCTION: A REVIEW
}

\author{
M.H. MILES \\ Department of Chemistry, University of La Verne \\ La Verne, CA 91750, USA \\ E-Mail: mmiles@ulv.eduor melmiles1@juno.com
}

\begin{abstract}
Three different sets of experiments conducted in the Navy Laboratory (NAWCWD) at China Lake, California (1990-1994) clearly established that helium- 4 is the main fusion product in the $\mathrm{Pd} / \mathrm{D}_{2} \mathrm{O}+\mathrm{LiOD}$ electrolysis system. A correlation between excess enthalpy and excess helium- 4 was measured in 18 out of 21 experiments. The observation of no excess enthalpy was correlated with no excess helium in 12 out of 12 experiments. Thus 30 out of 33 experiments agree with the hypothesis that the excess enthalpy produced in cold fusion studies is correlated with helium-4 production: $\mathrm{D}+\mathrm{D} \rightarrow{ }^{4} \mathrm{He}+23.8 \mathrm{MeV}$. Furthermore, the measured rate of helium- 4 production was always in the appropriate range of $10^{10}$ to $10^{12}$ atoms per second per watt of excess power.
\end{abstract}

\section{Introduction}

At the beginning of the cold fusion controversy in 1989, critics rightfully demanded evidence of nuclear products to confirm any fusion reactions. Because of the unusual rush to judgment of this new field as well as the early introduction of ridicule, cold fusion was quickly labeled as error, incompetence and fraud. ${ }^{1}$ Therefore, experimental results obtained in 1990 or later are largely ignored by the scientific community. Furthermore, the scientists who have continued with cold fusion research are labeled as "believers" and compared with the followers of religion. ${ }^{2}$

The China Lake experiments funded by the Office of Naval Research (ONR) were the first that clearly established that helium-4 is the main fusion product in palladium-heavy water electrolysis systems. Many other laboratories have now reported evidence of helium-4 in cold fusion experiments. Should these important experimental results be ignored simply because they were obtained in 1990 and later rather than in 1989? The purpose of this review is to present a summary of the evidence for helium- 4 production that was obtained in three separate sets of Navy experiments conducted in the time period of 1990 to 1994.

\section{First set of 15 Experiments (1990-1991)}

The first set of 15 experiments conducted at China Lake (1990-1991) used glass flasks (500 mL) to collect samples of the electrolysis gases. ${ }^{3}$ The entire system was self-flushing because of the continuous evolution of deuterium and oxygen gases. Furthermore, the gas collection system was always under positive pressure via the evolution of the effluent gases through an oil bubbler., ${ }^{3,4}$ Experimental details of the electrochemical cell and calorimetry as well as the day-by-day excess enthalpy measurements are presented elsewhere. ${ }^{3,4}$ The electrolysis gas samples collected in $500 \mathrm{~mL}$ glass flasks were sent to the University of Texas for helium analysis. ${ }^{5}$ The excess power $\left(\mathrm{P}_{\mathrm{EX}}\right)$ and helium- 4 measurements for the ten $\mathrm{Pd} / \mathrm{D}_{2} \mathrm{O}+\mathrm{LiOD}$ electrolysis samples are presented in Table 1. 
Table 1. Excess power and helium measurements for $\mathrm{Pd} / \mathrm{D}_{2} \mathrm{O}+0.2 \mathrm{M}$ LiOD experiments (1990).

\begin{tabular}{|c|c|c|c|c|}
\hline $\begin{array}{l}\text { Sample } \\
\text { (Date) }\end{array}$ & $\begin{array}{l}\mathrm{P}_{\mathrm{EX}} \\
(\mathrm{W})\end{array}$ & $\begin{array}{c}\mathrm{P}_{\text {out }} / \mathrm{P}_{\text {in }} \\
(\mathrm{X})\end{array}$ & $\begin{array}{c}{ }^{4} \mathrm{He} \\
\text { (Atoms/500 } \\
\mathrm{mL} \text { ) }\end{array}$ & ${ }^{4} \mathrm{He} / \mathrm{s} \bullet \mathrm{W}$ \\
\hline $12 / 14 / 90-\mathrm{A}$ & $0.52^{\mathrm{a}}$ & $1.20^{\mathrm{a}}$ & $10^{15}$ & $10^{12}$ \\
\hline 10/21/90-B & 0.46 & 1.27 & $10^{15}$ & $10^{12}$ \\
\hline $12 / 17 / 90-\mathrm{A}$ & $0.40^{\mathrm{b}}$ & $1.19^{\mathrm{b}}$ & $10^{14}$ & $10^{11}$ \\
\hline 11/25/90-B & 0.36 & 1.15 & $10^{15}$ & $10^{12}$ \\
\hline 12/17/90-B & $0.29^{\mathrm{b}}$ & $1.11^{\mathrm{b}}$ & $<10^{13}$ & $<10^{10}$ \\
\hline 11/20/90-A & 0.24 & 1.10 & $10^{14}$ & $10^{11}$ \\
\hline $11 / 27 / 90-\mathrm{A}$ & 0.22 & 1.09 & $10^{15}$ & $10^{12}$ \\
\hline 10/30/90-B & 0.17 & 1.12 & $10^{13}$ & $10^{10}$ \\
\hline 10/30/90-A & 0.14 & 1.08 & $10^{13}$ & $10^{10}$ \\
\hline 10/17/90-B & 0.07 & 1.03 & $<10^{13}$ & $<10^{10}$ \\
\hline
\end{tabular}

${ }^{a} \mathrm{i}=250 \mathrm{~mA} / \mathrm{cm}^{2}$. All other experiments used $\mathrm{i}=200 \mathrm{~mA} / \mathrm{cm}^{2}(500 \mathrm{~A})$.

b Possible calorimetric error due to low $\mathrm{D}_{2} \mathrm{O}$ solution level. This error was more serious for the 12/17/90-B sample and likely caused the excess power measurement to be too large.

The helium- 4 measurements at the University of Texas consisted of mass spectrometry observations of either no peaks or small, medium, and large helium-4 peaks. ${ }^{5}$ There were no control samples of known helium concentrations in $\mathrm{D}_{2}+\mathrm{O}_{2}$ mixtures for comparison. Initially, a detection limit of $8 \times 10^{11}$ atoms of helium- 4 was estimated $^{5}$, but the actual detection limits were expected to be higher. ${ }^{4}$ In retrospect, this initial detection limit exceeds the sensitivity of the best commercial laboratory that was later used for the detection of helium-4 $\left( \pm 1.0 \times 10^{12}\right.$ atoms or $\left.\pm 0.10 \mathrm{ppb}\right)$. Additional experiments using metal flasks showed that the mean background helium concentration in our system was $4.4 \pm 0.6 \mathrm{ppb}$ or $5.1 \pm 0.7 \times 10^{13}{ }^{4} \mathrm{He}$ atoms $/ 500 \mathrm{~mL}{ }^{6,7}$ Therefore, in Table 1 , the small, medium, and large helium- 4 peaks are assigned values of $10^{13}, 10^{14}$, and $10^{15}$ helium- 4 atoms per $500 \mathrm{~mL}$ above background levels. ${ }^{7}$ This assignment yields helium-4 production rates of $10^{10}$ to $10^{12}{ }^{4} \mathrm{He} \mathrm{s}^{-1} \mathrm{~W}^{-1}$. The first sample (10/17/90-B) was taken early in the experiment before the excess enthalpy effect developed ${ }^{4}$, thus this sample acts as a control. When excess enthalpy was measured, 8 out of 9 samples showed excess helium-4. The one exception (12/17/90-B) could possibly be explained as a calorimetric error due to the unusually low level of $\mathrm{D}_{2} \mathrm{O}$ in this cell. ${ }^{7}$

The diffusion of atmospheric helium into the $500 \mathrm{~mL}$ glass flasks must be considered in this first set of experiments. Based on the measured surface area and thickness of these Pyrex flasks, the theoretical rate of atmospheric helium diffusing into the flasks is $2.6 \times 10^{12}$ atoms/day. ${ }^{6}$ Actual experimental measurements by two different commercial laboratories yielded mean values of $3.2 \times 10^{12}$ atoms/day for nitrogen-filled flasks and $2.1 \times 10^{12}$ atoms/day for flasks filled with $\mathrm{D}_{2}+\mathrm{O}_{2}$ electrolysis gases. ${ }^{6}$ Hydrogen and deuterium gases also diffuse through glass, thus it is reasonable that the outward diffusion of deuterium could somewhat slow the rate of the inward diffusion of atmospheric helium, and this was observed experimentally. ${ }^{4}$ Based on the experimental diffusion rate of $2.1 \times 10^{12}$ atoms/day for glass flasks containing $\mathrm{D}_{2}+\mathrm{O}_{2}$, it would require 24 days for the diffusion of atmospheric helium into these flasks to equal the background helium level $\left(5.1 \times 10^{13}\right.$ atoms $\left./ 500 \mathrm{~mL}\right)$ for our system. Therefore, the diffusion of atmospheric helium into these glass sample flasks can be ruled out as an experimental error source. This information was not available in our earlier publications..$^{3-5}$

Five additional control samples were generated using $\mathrm{Pd} / \mathrm{H}_{2} \mathrm{O}+\mathrm{LiOH}$. No excess enthalpy was measured calorimetrically at China Lake and no helium-4 was detected in any of these samples by the University of Texas. ${ }^{3,4}$ This provided additional evidence that contamination by atmospheric helium could be ruled out. Including the first sample (10/17/90-B, Table 1) from the $\mathrm{Pd} / \mathrm{D}_{2} \mathrm{O}+\mathrm{LiOD}$ study, there were a total of six samples that showed no excess helium- 4 when the calorimetry measured no excess enthalpy.

\section{Second Set of 3 Experiments (1991-1992)}


Most of our experiments in 1991 failed to generate any significant anomalous effects. Late in that year, two experiments began to produce excess enthalpy. Glass flasks $(500 \mathrm{~mL})$ were again used to collect three electrolysis gas samples. However, these samples were sent to Rockwell International in order to obtain more accurate helium- 4 measurements $( \pm 0.10 \mathrm{ppb})$. Furthermore, measurements of helium- 4 for these samples were continued over a period exceeding 100 days to provide for the accurate determination of the rate of atmospheric helium diffusing into these glass flasks. The results of this study are present in Fig. 1.

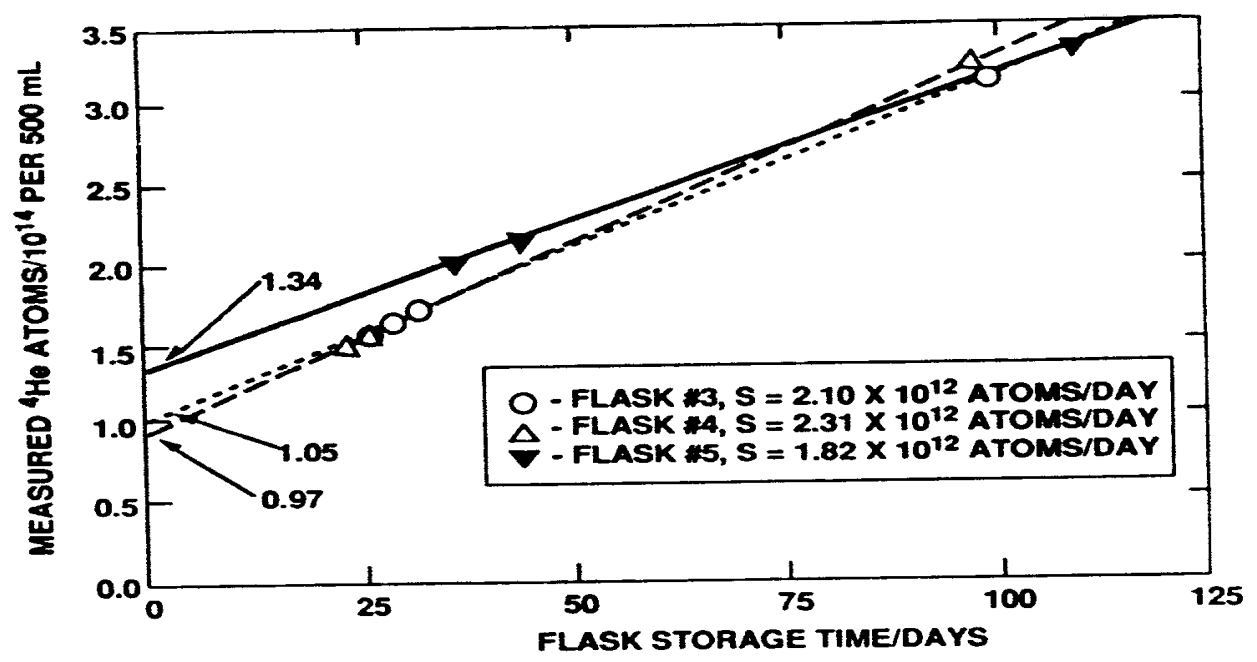

Figure 1. Measurements of helium-4 by Rockwell International for three glass flasks filled with $\mathrm{D}_{2}+\mathrm{O}_{2}$ from $\mathrm{Pd} / \mathrm{D}_{2} \mathrm{O}$ electrolysis involving excess enthalpy production.

It was this same set of experiments that determined a mean rate of $2.1 \times 10^{12}$ atoms/day for atmospheric helium diffusing into these flasks. The three glass flasks gave individual values of $2.10 \times 10^{12}, 2.31 \times 10^{12}$, and $1.82 \times 10^{12}$ atoms/day (Figure 1). As shown in Figure 1, the three lines are extrapolated to zero time to yield $1.34 \times 10^{14}, 1.05 \times 10^{14}$ and $0.97 \times 10^{14}{ }^{4} \mathrm{He}$ atoms per $500 \mathrm{~mL}$. These values are the concentrations of helium-4 at the time when the samples were collected. Our system background level of helium- $4\left(0.51 \times 10^{14}\right.$ atoms $\left./ 500 \mathrm{~mL}\right)$ can now be subtracted to find the amount of helium-4 produced per second per watt (W) of excess power. The experimental results as well as the results of these calculations are given in Table 2. It is interesting to note in Table 2 that a Geiger-Mueller (GM) alpha-beta-gamma detector (Ludlum Model 44-7) positioned near the electrochemical cells recorded an anomalous high count $(27 \sigma)$ during the time period when two of these samples were collected. ${ }^{6}$ 
Table 2. Second set of experiments yielding excess power and helium production during $\mathrm{D}_{2} \mathrm{O}$ electrolysis

\begin{tabular}{|l|c|c|c|c|}
\hline \multicolumn{1}{|c|}{$\begin{array}{c}\text { Sample } \\
\text { (Date) }\end{array}$} & $\begin{array}{c}\mathrm{P}_{\mathrm{EX}} \\
(\mathrm{W})\end{array}$ & $\begin{array}{c}\mathrm{P}_{\text {out }} / \mathrm{P}_{\text {in }} \\
(\mathrm{X})\end{array}$ & $\begin{array}{c}{ }^{4} \mathrm{He}^{\mathrm{a}} \\
(\text { Atoms } / 500 \mathrm{~mL})\end{array}$ & ${ }^{4} \mathrm{He} / \mathrm{sW}^{\mathrm{b}}$ \\
$\begin{array}{l}12 / 30 / 91-\mathrm{B} \\
\text { (Flask 5) }\end{array}$ & $0.100^{\mathrm{c}}$ & 1.08 & $1.34 \times 10^{14}$ & $2 \times 10^{11}$ \\
$\begin{array}{l}12 / 30 / 91-\mathrm{A} \\
\text { (Flask 3) }\end{array}$ & $0.050^{\mathrm{c}}$ & 1.02 & $1.05 \times 10^{14}$ & $2 \times 10^{11}$ \\
$\begin{array}{l}01 / 03 / 92-\mathrm{B} \\
\text { (Flask 4) }\end{array}$ & $0.020^{\mathrm{d}}$ & 1.01 & $0.97 \times 10^{14}$ & $5 \times 10^{11}$ \\
\hline
\end{tabular}

a Error range reported by Rockwell International was $\pm 0.01 \times 10^{14}$ atoms $/ 500$ $\operatorname{mL}( \pm 1 \sigma)$.

b Corrected for a background level of $5.1 \times 10^{13}$ atoms $/ 500 \mathrm{~mL}$.

c $\mathrm{I}=525 \mathrm{~mA}$. An anomalous GM count $(27 \sigma)$ was measured during this period.

d $\mathrm{I}=500 \mathrm{~mA}$. The GM count rate was within the normal range.

It requires $4440 \mathrm{~s}$ to produce $500 \mathrm{~mL}$ of electrolysis gases $\left(\mathrm{D}_{2}, \mathrm{O}_{2}\right)$ at $525 \mathrm{~mA}$ for normal laboratory conditions ( $\mathrm{T}=296 \mathrm{~K}, \mathrm{P}=690$ Torr) at China Lake. ${ }^{7} \quad$ Therefore, the calculation for the first sample (12/30/91-B) in Table 2 is given in Equation 1.

$$
\frac{(1.34-0.51) \times 10^{14} \mathrm{He} \text { atoms } / 500 \mathrm{~mL}}{(4440 \mathrm{~s} / 500 \mathrm{~mL})(0.100 \mathrm{~W})}=1.9 \times 10^{11} \mathrm{He} \text { atoms } \mathrm{s}^{-1} \mathrm{~W}^{-1}
$$

This sample likely represents the most accurate combination of excess power and excess helium measurements in these studies, and the result is close to the theoretical rate of $2.6 \times 10^{11}{ }^{4} \mathrm{He} \mathrm{s}^{-1} \mathrm{~W}^{-1}$ for the $\mathrm{D}+\mathrm{D} \rightarrow{ }^{4} \mathrm{He}+23.8$ $\mathrm{MeV}$ fusion reaction. ${ }^{6}$

A closer examination of Table 2 shows that the different amounts of helium-4 reported by Rockwell International are statistically very significant. The error in these measurements of helium-4 was only $\pm 0.01 \times 10^{14}$ atoms $/ 500 \mathrm{~mL}( \pm 1 \sigma)$, therefore the difference between the highest $\left(1.34 \times 10^{14}\right.$ atoms $\left./ 500 \mathrm{~mL}\right)$ and the lowest $\left(0.97 \times 10^{14}\right.$ atoms $\left./ 500 \mathrm{~mL}\right)$ measurements (Table 2$)$ is a $37 \sigma$ effect. Furthermore, the background level of helium- 4 in our system was later accurately measured as $0.51 \pm 0.06 \times 10^{14}$ atoms $/ 500 \mathrm{~mL}$. ${ }^{6,7}$ Therefore, the highest level of helium-4 measured in Table $2\left(1.34 \times 10^{14}\right.$ atoms $\left./ 500 \mathrm{~mL}\right)$ is statistically a $14 \sigma$ effect above the system background i.e. $(1.34-0.51) \times 10^{14} / 0.06 \times 10^{14}$. Except perhaps for the cold fusion field, any measurements that produce even a $5 \sigma$ effect are considered to be very significant by the scientific community. During these experiments, neither Rockwell International nor the China Lake laboratory knew results of both the excess power and helium measurement until after this study was completed and all results were reported to a third party (J.J. Lagowski of the University of Texas). ${ }^{6}$ Moreover, the background helium-4 level for our system was not determined until several years later (see Table 3).

\section{Third Set of 15 Experiments (1993-1994)}

The final set of 15 China Lake experiments employed metal flasks to collect the electrolysis gas samples. ${ }^{8,9}$ This eliminates the diffusion of any atmospheric helium into the collected gas sample sent out for analysis. For these experiments, the helium analysis was performed by the U.S. Bureau of Mines laboratory in Amarillo, Texas. A major goal of these studies was to determine the background level of helium-4 in our electrolysis system. Therefore, everything was arranged exactly as in the previous two sets of experiments except that metal flasks were used in place of the glass flasks for the collection of electrolysis gas samples. As in previous experiments, the palladium material was in the form of cylindrical rods or wires unless stated otherwise.

Table 3 presents the experimental results for six control experiments where no excess power was measured at any time over the entire duration of the study. ${ }^{9}$ One experiment used $\mathrm{H}_{2} \mathrm{O}+\mathrm{LiOH}$ while the other five employed $\mathrm{D}_{2} \mathrm{O}+\mathrm{LiOD}$ solutions.

Table 3. Helium measurement in control experiments using metal flasks. No excess power was measured. 


\begin{tabular}{|c|c|c|c|}
\hline $\begin{array}{c}\text { Electrode } \\
\text { (Dimensions) }\end{array}$ & $\begin{array}{c}\text { Flask/Cell } \\
\text { (Date) }\end{array}$ & $\begin{array}{l}{ }^{4} \mathrm{He}^{\mathrm{a}} \\
(\mathrm{ppb})\end{array}$ & $\begin{array}{c}{ }^{4} \mathrm{He} \\
\text { (Atoms } / 500 \mathrm{~mL} \text { ) }\end{array}$ \\
\hline $\begin{array}{l}\mathrm{Pd}^{\mathrm{b}} \\
(4 \mathrm{~mm} \times 1.6 \mathrm{~cm})\end{array}$ & $\begin{array}{c}1 / \mathrm{C} \\
(2 / 24 / 93)\end{array}$ & $4.8 \pm 1.1$ & $5.5 \times 10^{13}$ \\
\hline $\begin{array}{l}\text { Pd- }-\mathrm{Ag}^{\mathrm{b}} \\
(4 \mathrm{~mm} \times 1.6 \mathrm{~cm})\end{array}$ & $\begin{array}{c}2 / \mathrm{D} \\
(2 / 24 / 93)\end{array}$ & $4.6 \pm 1.1$ & $5.2 \times 10^{13}$ \\
\hline $\begin{array}{l}\mathrm{Pd}^{\mathrm{b}} \\
(4 \mathrm{~mm} \times 1.6 \mathrm{~cm})\end{array}$ & $\begin{array}{c}3 / \mathrm{C} \\
(2 / 28 / 93)\end{array}$ & $4.9 \pm 1.1$ & $5.6 \times 10^{13}$ \\
\hline $\begin{array}{l}\mathrm{Pd}-\mathrm{Ag}^{\mathrm{b}} \\
(4 \mathrm{~mm} \times 1.6 \mathrm{~cm})\end{array}$ & $\begin{array}{c}4 / \mathrm{D} \\
(2 / 28 / 93)\end{array}$ & $3.4 \pm 1.1$ & $3.9 \times 10^{13}$ \\
\hline $\begin{array}{l}\mathrm{Pd}^{\mathrm{c}} \\
(1 \mathrm{~mm} \times 1.5 \mathrm{~cm})\end{array}$ & $\begin{array}{c}3 / \mathrm{C} \\
(7 / 7 / 93)\end{array}$ & $4.5 \pm 1.5$ & $5.1 \times 10^{13}$ \\
\hline $\begin{array}{l}\mathrm{Pd}^{\mathrm{d}} \\
(4.1 \mathrm{~mm} \times 1.9 \mathrm{~cm})\end{array}$ & $\begin{array}{c}3 / \mathrm{D} \\
3 / 30 / 94\end{array}$ & $4.6 \pm 1.4$ & $5.2 \times 10^{13}$ \\
\hline (Mean) & & $(4.5 \pm 0.5)$ & $\left(5.1 \pm 0.6 \times 10^{13}\right)$ \\
\hline
\end{tabular}

${ }^{a}$ Helium analysis by U.S. Bureau of Mines, Amarillo, Texas.

b $\mathrm{D}_{2} \mathrm{O}+\mathrm{LiOD}(\mathrm{I}=500 \mathrm{~mA})$.

${ }^{c} \mathrm{H}_{2} \mathrm{O}+\mathrm{LiOH}(\mathrm{I}=500 \mathrm{~mA})$.

${ }^{\mathrm{d}} \mathrm{D}_{2} \mathrm{O}+\mathrm{LiOD}(\mathrm{I}=600 \mathrm{~mA})$.

The experiments in Table 3 established that the mean background level of helium- 4 in our system was $5.1 \pm 0.6 \times 10^{13}$ atoms $/ 500 \mathrm{~mL}(4.5 \pm 0.5 \mathrm{ppb})$. Theoretical calculations show that this background helium-4 is due to the diffusion of atmospheric helium through the thick rubber vacuum tubing $(50 \mathrm{~cm}$ length) that was used to connect our electrolysis cell to the metal collection flask., ${ }^{9,10}$ The diffusion of atmospheric helium through the glass components of our electrolysis cell is theoretically much too small to explain our measured background level of helium-4. The background level of helium can be reduced to $0 \pm 1 \mathrm{ppb}$ when metal lines are used to replace the rubber vacuum tubing. ${ }^{11}$

Table 4 shows the results for similar experiments that produced excess power and used metal flasks to collect the electrolysis gas samples. ${ }^{9}$ Details of the China Lake calorimetry that was used during this period are presented elsewhere. ${ }^{12}$ The amount of helium- 4 measured is higher for each study than the amount found in any of the control experiments. 
Table 4. Excess power and helium measurements for experiments using metal flasks.

\begin{tabular}{|c|c|c|c|c|c|}
\hline $\begin{array}{c}\text { Electrode } \\
\text { (Dimensions) }\end{array}$ & $\begin{array}{l}\text { Flask/Cell } \\
\text { (Date) }\end{array}$ & $\begin{array}{l}\mathrm{P}_{\mathrm{x}} \\
(\mathrm{W})\end{array}$ & $\begin{array}{l}{ }^{4} \mathrm{He}^{\mathrm{a}} \\
(\mathrm{ppb})\end{array}$ & $\begin{array}{c}{ }^{4} \mathrm{He} \\
\text { (Atoms/500 } \\
\mathrm{mL} \text { ) }\end{array}$ & ${ }^{4} \mathrm{He} \mathrm{s} / \mathrm{W}^{\mathrm{b}}$ \\
\hline $\begin{array}{l}\text { Pd Sheet }^{\mathrm{c}} \\
(1.0 \mathrm{~mm} \times 3.2 \mathrm{~cm} \times 1.6 \mathrm{~cm})\end{array}$ & $\begin{array}{l}3 / \mathrm{A} \\
(5 / 21 / 93)\end{array}$ & 0.055 & $9.0 \pm 1.1$ & $1.02 \times 10^{14}$ & $1.6 \times 10^{11}$ \\
\hline $\begin{array}{l}\mathrm{Pd}^{\mathrm{c}} \\
(1 \mathrm{~mm} \times 2.0 \mathrm{~cm})\end{array}$ & $\begin{array}{l}4 / \mathrm{B} \\
(5 / 21 / 93)\end{array}$ & 0.040 & $9.7 \pm 1.1$ & $1.09 \times 10^{14}$ & $2.5 \times 10^{11}$ \\
\hline $\begin{array}{l}\mathrm{Pd}^{\mathrm{c}} \\
(1 \mathrm{~mm} \times 1.5 \mathrm{~cm})\end{array}$ & $\begin{array}{l}1 / \mathrm{C} \\
(5 / 30 / 93)\end{array}$ & 0.040 & $7.4 \pm 1.1$ & $0.84 \times 10^{14}$ & $1.4 \times 10^{11}$ \\
\hline $\begin{array}{l}\mathrm{Pd}^{\mathrm{c}} \\
(2 \mathrm{~mm} \times 1.2 \mathrm{~cm})\end{array}$ & $\begin{array}{l}2 / \mathrm{D} \\
(5 / 30 / 93)\end{array}$ & 0.060 & $6.7 \pm 1.1$ & $0.75 \times 10^{14}$ & $7.0 \times 10^{10}$ \\
\hline $\begin{array}{l}\mathrm{Pd}^{\mathrm{d}} \\
(4 \mathrm{~mm} \times 2.3 \mathrm{~cm})\end{array}$ & $\begin{array}{l}1 / \mathrm{A} \\
(7 / 7 / 93)\end{array}$ & 0.030 & $5.4 \pm 1.5$ & $0.61 \times 10^{14}$ & $7.5 \times 10^{10}$ \\
\hline $\begin{array}{l}\mathrm{Pd}^{\mathrm{d}} \\
(6.35 \mathrm{~mm} \times 2.1 \mathrm{~cm})\end{array}$ & $\begin{array}{l}2 / \mathrm{A} \\
(9 / 13 / 94)\end{array}$ & 0.070 & $7.9 \pm 1.7$ & $0.90 \times 10^{14}$ & $1.2 \times 10^{11}$ \\
\hline $\begin{array}{l}* \mathrm{Pd}-\mathrm{B}^{\mathrm{d}} \\
(6 \mathrm{~mm} \times 2.0 \mathrm{~cm})\end{array}$ & $\begin{array}{l}3 / \mathrm{B} \\
(9 / 13 / 94)\end{array}$ & 0.120 & $9.4 \pm 1.8$ & $1.07 \times 10^{14}$ & $1.0 \times 10^{11}$ \\
\hline
\end{tabular}

a Helium analysis by U.S. Bureau of Mines, Amarillo, Texas.

b Corrected for background helium level of $0.51 \times 10^{14}$ atoms $/ 500 \mathrm{~mL}$.

c $\mathrm{D}_{2} \mathrm{O}+\mathrm{LiOD}(\mathrm{I}=400 \mathrm{~mA})$.

d $\mathrm{D}_{2} \mathrm{O}+\operatorname{LiOD}(\mathrm{I}=500 \mathrm{~mA})$.

* NRL material prepared by Dr. M.A. Imam.

The rate of helium- 4 production shown in Table 4 ranges from $7.0 \times 10^{10}$ to $2.5 \times 10^{11}$ atoms s${ }^{-1} \mathrm{~W}^{-1}$. As found in the previous two sets of experiments, these results are again reasonably close to the theoretical rate of $2.6 \times 10^{11}{ }^{4} \mathrm{He} \mathrm{s}^{-1} \mathrm{~W}^{-1}$ for the $\mathrm{D}+\mathrm{D}$ fusion reaction. One of the samples in Table 4 that produced excess enthalpy and correlated helium-4 production was the novel Pd-B material made by Dr. Imam at the Naval Research Laboratory (NRL). ${ }^{13}$ This material has produced excess enthalpy in nearly every experiment, and extensive calorimetric measurements have been reported. ${ }^{14-20}$

There were two measurements using metal flasks for collecting electrolysis gas samples that produced excess power but showed no excess helium $-4{ }^{9}$. Both measurements involved a cell that used a Pd-Ce alloy cathode. These two measurements recorded 0.17 and $0.30 \mathrm{~W}$ of excess power but only $4.6 \pm 1.4$ and $4.7 \pm 1.3 \mathrm{ppb}$ of helium-4, respectively, in the electrolysis gas samples. If experimental error is ruled out, then it may be speculated that either the Pd-Ce alloy involves a different fusion reaction or that the helium atoms produced remained trapped in the Pd-Ce electrode. ${ }^{9}$

In summary, the final set of China Lake experiments employed metal flasks to collect the electrolysis gas samples. When excess enthalpy was measured, 7 out of 9 samples registered excess helium- 4 production (Table 4). When no excess heat was present, all 6 samples showed no excess helium-4 (Table 3).

\section{Discussion}

The results of these three sets of experiments established that most of the helium-4 produced in the fusion reaction is released to the electrolysis gas stream. This suggests that the $\mathrm{D}+\mathrm{D}$ fusion reaction either occurs at or near the electrode surface or that the heavily deuterided palladium somehow allows the helium-4 to readily escape from the bulk material. Assuming that ${ }^{2} \mathrm{D}+{ }^{2} \mathrm{D} \rightarrow{ }^{4} \mathrm{He}+23.8 \mathrm{MeV}$ is the fusion reaction and that all of helium-4 produced escapes to the electrolysis gas stream, then the theoretical relationship between the excess power and the helium concentration in the gas sample can be calculated. Results for these calculations are shown in Table 5 for a typical electrolysis current of $500 \mathrm{~mA}$.

Table 5. Theoretical relationship between excess power and the helium-4 concentration in the electrolysis gases. The magnitude of experimental error is also presented. 


\begin{tabular}{|c|c|c|c|c|}
\hline $\begin{array}{c}\mathrm{P}_{\mathrm{x}} \\
(\mathrm{W})\end{array}$ & $\begin{array}{c}{ }^{4} \mathrm{He}^{\mathrm{a}} \\
(\mathrm{ppb})\end{array}$ & $\begin{array}{c}{ }^{4} \mathrm{He} \\
\left(\begin{array}{c}\text { Atoms } / 500 \\
\mathrm{~mL})\end{array}\right.\end{array}$ & $\begin{array}{c}{ }^{4} \mathrm{He} \\
\text { Error }^{\mathrm{b}} \\
\%\end{array}$ & $\begin{array}{c}\text { Calorimetric } \\
\text { Error }^{\mathrm{c}} \%\end{array}$ \\
\hline 0.020 & 2.2 & $2.55 \times 10^{13}$ & 45 & 100 \\
0.050 & 5.6 & $6.38 \times 10^{13}$ & 18 & 40 \\
0.100 & 11.2 & $1.28 \times 10^{14}$ & 8.9 & 20 \\
0.200 & 22.4 & $2.55 \times 10^{14}$ & 4.5 & 10 \\
0.500 & 56.0 & $6.38 \times 10^{14}$ & 1.8 & 4 \\
1.000 & 112.0 & $1.28 \times 10^{15}$ & 0.89 & 2 \\
10.000 & 1112.0 & $1.28 \times 10^{16}$ & 0.089 & 0.2 \\
\hline
\end{tabular}

a $\quad$ For $\mathrm{I}=500 \mathrm{~mA}$ assuming ${ }^{2} \mathrm{D}+{ }^{2} \mathrm{D} \rightarrow{ }^{4} \mathrm{He}+23.8 \mathrm{MeV}$.

b For $\pm 1.0 \mathrm{ppb}$ error.

c For $\pm 0.020 \mathrm{~W}$ error.

NOTE: N. Lewis (Cal Tech) and D. Albagli (MIT) reported gas-phase helium-4 detection limits of $1000 \mathrm{ppb}$ (1 ppm).

The excess power measurements in the China Lake experiments ranged from $0.52 \mathrm{~W}$ to $0.020 \mathrm{~W}$ (Tables 1 , 2, 4). Larger excess power effects would be helpful, but the fact that increasing the temperature increases the excess power (positive feedback) was not known at the time of these experiments. ${ }^{14-21}$ Furthermore, the China Lake calorimetry was not designed to operate at higher temperatures. Future studies of helium-4 production at higher temperatures are desirable that use the Fleischmann-Pons Dewar calorimetry where the calorimetric error is less than $\pm 0.001 \mathrm{~W} \cdot{ }^{14,15,22}$ It should be noted that two prominent studies in 1989 reported evidence against any helium- 4 in the gas phase while using a detection limit of $1000 \mathrm{ppb}$ (Table 5). An excess power of nearly $10 \mathrm{~W}$ would be required before such instruments would detect any helium-4 production (Table 5). Ten watts of excess power would drive many cold fusion calorimetric cells to boiling.

Combining the three different sets of China Lake experiments (Tables 1,2,4) shows a correlation between the measurements of excess enthalpy and excess helium- 4 in 18 out of 21 experiments. The three exceptions are the two studies involving the Pd-Ce alloy and an experiment with a possible calorimetric error due to an unusually low $\mathrm{D}_{2} \mathrm{O}$ level (Table 1, sample 12/17/90-B). There were also twelve studies where no excess enthalpy was measured by the calorimetry (Table 3 plus six control studies in the first set of experiments). When no excess enthalpy was measured, 12 out of the 12 experiments produced no excess helium- 4 . Thus 30 out of 33 experiments conducted in the Navy laboratory at China Lake agree with the hypothesis that the excess enthalpy in cold fusion experiments is correlated with helium-4 production. An exact statistical treatment shows that the probability is only one in 750,000 that the China Lake set of heat and helium measurements could be this well correlated due to random experimental errors. ${ }^{9}$ Furthermore, the rate of helium-4 production was always in the appropriate range of $10^{10}$ to $10^{12}$ atoms per second per watt of excess power for all three sets of experiments. These results stand as solid evidence that the main process producing excess enthalpy in the $\mathrm{Pd} / \mathrm{D}_{2} \mathrm{O}+\mathrm{LiOD}$ electrolysis system is $\mathrm{D}+\mathrm{D}$ fusion with helium- 4 as the major product.

Many other research groups have now reported evidence of helium-4 production in cold fusion experiments. ${ }^{1}$ These groups include Bockris et $\mathrm{al}^{23}$, Liaw et $\mathrm{al}^{24}$, and $\mathrm{McKubre}^{25}$. An important recent study in Italy suggests that the measurement of helium- 4 can even replace the calorimetry as the most accurate measurement of the excess enthalpy. ${ }^{26}$

The D+D fusion reaction offers a solution to the world's energy need and the eventual shortage of oil and other chemical fuels. A simple calculation shows that there are sufficient deuterium atoms $\left(10^{43}\right)$ in the oceans of the world to provide for the present energy needs of the world's population for more than one billion years.

\section{Summary}

The Navy experiments conducted in the laboratory at China Lake, California were the first to clearly establish that helium- 4 is the main fusion product in the $\mathrm{Pd} / \mathrm{D}_{2} \mathrm{O}+\mathrm{LiOD}$ electrolysis system. The first set of experiments was conducted in 1990. Two additional sets of Navy experiments verified the first study and provided convincing evidence that the excess enthalpy in cold fusion experiments is correlated with the $\mathrm{D}+\mathrm{D} \rightarrow{ }^{4} \mathrm{He}+$ 23.8 MeV fusion reaction. These results for helium-4 production have now been substantiated by many other research groups. 


\section{References}

1. C.G. Beaudette, "Excess Heat: Why Cold Fusion Research Prevailed", $2^{\text {nd }}$ Edition, Oak Grove Press (ISBN 0-9678548-3-0), South Bristol, Maine, 2002.

2. S.K. Ritter, Chem. Eng. News, 81, No. 34, p. 33 (2003).

3. M.H. Miles, B.F. Bush, G.S. Ostrom, and J.J. Lagowski in "The Science of Cold Fusion", ICCF-2 Proceedings, T. Bressani, E. Del Giudice and G. Preparata, Editors, Italian Physical Society, pp. 363372 (1991).

4. M.H. Miles, R.A. Hollins, B.F. Bush, J.J. Lagowski, and R.E. Miles, J. Electrochem. Soc., 346, 99 (1993).

5. M.H. Miles, G.S. Ostrom, B.F. Bush, and J.J. Lagowski, J, Electrochem. Soc., 304, 271 (1991).

6. M.H. Miles, B.F. Bush, and J. J. Lagowski, Fusion Technol., 25, 478 (1994).

7. M.H. Miles, J. Phys. Chem. B, 102, 3642 1998)

8. M.H. Miles, K.B. Johnson, and M.A. Imam in "Progress in New Hydrogen Energy", ICCF-6 Proceedings, M.Okamoto, Editor, Vol. 1, pp. 20-28 (1996).

9. M.H. Miles, B.F. Bush, and K.B. Johnson, Anomalous Effects in Deuterated Systems", NAWCWPNS TP 8302, 98 pp., September 1996.

10. M.H. Miles and B.F. Bush, Trans. Fusion Technol., 26, 156 (1994).

11. B.F. Bush, private communication. See also ICCF-7 Proceedings p. 42, 1998.

12. M.H. Miles, B.F. Bush, and D.E. Stilwell, J. Phys. Chem., 98, 1948 (1994).

13. B. Daviss, New Scientist, 177, No. 2388, 36 (2003).

14. M.H. Miles, M. Fleischmann, and M.A. Imam, "Calorimetric Analysis of a Heavy Water Electrolysis Experiment Using a Pd-B Alloy Cathode”, NRL/MR/6320 — 01-8526, 155 pp., March 26, 2001.

15. S. Szpak, P.A. Mosier-Boss, M.H. Miles, M.A. Imam, and M. Fleischmann in "Thermal and nuclear Aspects of the $\mathrm{Pd} / \mathrm{D}_{2} \mathrm{O}$ System", Vol. 1, S. Szpak and P.A. Mosier-Boss, Editors, Technical Report 1862, pp. 31-89, February 2002.

16. M.H. Miles in "Conference Proceedings - ICCF-8", Vol. 70, F. Scaramuzzi, Editor, Italian Physical Society (ISBN 88-7794-256-8), pp. 97-104, May 2000.

17. M.H. Miles, M.A. Imam, and M. Fleischmann in "Conference Proceedings, ICCF-8", Vol. 70, F. Scaramuzzi, Editor, Italian Physical Society (ISBN 88-7794-256-8), pp. 105-119, May 2000.

18. M.H. Miles, M.A. Imam, and M. Fleischmann in "Energy and Electrochemical Processes For a Cleaner Environment", C. Comninellis, M. Doyle, and J. Winnick, Editors, Proceedings Volume 2001-23, The Electrochemical Society (ISBN 1-56677-356-3), Pennington, NJ, 2001.

19. M.H. Miles, M.A. Imam, and M. Fleischmann in "Batteries and Supercapacitors", G.A. Nazri, E. Takeuchi, R. Koetz, and B. Scrosati, Editors, Proceedings Volume 2001-21, The Electrochemical Society (ISBN 1-56677-354-7), Pennington, NJ, 2003

20. M.H. Miles, M.A. Imam, and M. Fleischmann in "ICCF-10 Proceedings", 2003 (in press). 
21. M. Fleischmann in "Condensed Matter Nuclear Science, ICCF-9 Proceedings", Xing Z. Li, Editor, Tsinghua University Press (ISBN 7-302-06489-X), Beijing, China, pp. III-XVII (2003).

22. M. Fleischmann in "ICCF-10 Proceedings", 2003 (in press).

23. C.C. Chien, D. Hodko, Z. Minevski, and J.O’M. Bockris, J. Electroanal. Chem., 338, 189 (1992).

24. B.Y. Liaw, P. Tao, P. Turner, and B.E. Liebert, J. Electroanal. Chem., 319, 161 (1991).

25. M. McKubre, F. Tanzella, P. Tripodi, and P. Hagelstein in "Conference Proceedings, ICCF-8", F. Scaramuzzi, Editor, Italian Physical Society (ISBN 88-7794-256-8), pp. 3-10, May 2000.

26. A. DeNinno, A. Frattolillo, A. Rizzo, and E. Del Giudice in "ICCF-10 Proceedings", 2003 (in press). 